\title{
BUREAU CENTRAL INTERNATIONAL DES TÉLÉGRAMMES ASTRONOMIQUES
}

\author{
CIPHER CODE FOR ASTRONOMICAL TELEGRAMS
}

adopted by the International Astronomical Union at the Paris Meeting July I935, and amended at the Zürich Meeting August I948, to be used from I948 November I

\section{(I) Communication of discovery of comet or planet}

Discoverer, object, time of observation, position, motion, magnitude and description of physical appearance are communicated according to the following scheme:

(a) The name of discoverer or, in the case of the rediscovery of a periodic comet, the generally used name of object, for instance Neujmin $\mathrm{x}$. The rediscoverer of a periodic comet should be treated as observer.

(b) A word describing the nature of the object: comet, planet or object.

(c) The name of the observer.

(d) Group of five figures, giving the day of the month (two figures), the magnitude (two figures) and a communication concerning the physical appearance of the object (one figure) according to the following schedule:

\begin{tabular}{|c|c|c|c|}
\hline & $\begin{array}{c}\text { Nothing reported } \\
\text { about tail }\end{array}$ & Tail $<1^{\circ}$ & Tail $>1^{\circ}$ \\
\hline $\begin{array}{c}\text { Stellar appearance } \\
\text { Nothing reported about ap- } \\
\text { pearance of the object }\end{array}$ & 0 & 2 & 3 \\
$\begin{array}{c}\text { itself } \\
\text { Object diffuse, without central } \\
\text { condensation or nucleus } \\
\text { Object diffuse, with central } \\
\text { condensation or nucleus }\end{array}$ & 4 & 5 & 6 \\
\hline
\end{tabular}

(e) The name of the month.

(f) Group of five figures giving the time of observation (universal time, reckoned from Greenwich mean midnight). Hours (two figures), minutes (two figures) and tenths of a minute are given.

(g) Group of five figures giving the observed right ascension (mean place referred to the mean equinox of the beginning of the year, if not otherwise stated). Hours (two figures), minutes of time (two figures) and, for approximate positions, tenths of a minute of time are given (cf. Example I), while for accurate positions the tens of the seconds of time are given (cf. Example 2).

(h) Group of five figures giving the observed declination (mean place referred to the mean equinox of the beginning of the year, if not otherwise stated). The first figure of the group is I or 2 according as the declination is negative or positive. The next two figures give the degrees, the last two figures the minutes of arc of the declination.

(i) Group of five figures, of which the first figure is 8 . The next two figures give the units of the seconds of time and tenths of seconds of time of the right ascension (continuation of $(g))$. The last two figures give the seconds of arc of the declination. When the observed position is approximate, this group is omitted.

(j) Group of five figures giving the daily motion of the object in right ascension. The first figure of the group is I or 2 according as the daily motion in right ascension is negative or positive. The next two figures give the minutes of time and the last two

$$
506
$$


figures the seconds of time of the daily motion in right ascension. When no daily motion is to be communicated, this group is omitted.

(k) Group of five figures giving the daily motion of the object in declination. The first figure of the group is I or 2 according as the daily motion in declination is negative or positive. The next two figures give the degrees and the last two figures the minutes of arc of the daily motion in declination. When no daily motion is to be communicated, this group is omitted.

(l) Group of five figures (check number) computed as the sum of the preceding five-figure groups. If this sum is a number of six figures, the left hand figure (first figure) is discarded.

(m) The name of the communicator.

Example I (approximate position).

Telegram I935 Jan. 9:

Johnson comet Johnson 08104 January I8282 00598 I5103 200162010382206 Johannesburg Observatory.

A new comet has been discovered by Johnson as follows:

$\begin{array}{ccccc}\text { I935 } & \text { U.T. } & \alpha_{1935 \cdot 0} & \delta_{1935 \cdot 0} & \text { Mag. } \\ \text { Jan. } 8 & \mathrm{I} 8^{\mathrm{h}} 28^{\mathrm{m} \cdot 2} & \mathrm{O}^{\mathrm{h}} 59^{\mathrm{m} \cdot 8} & -5^{\circ} 3^{\prime} & \text { IO }^{\mathrm{m}}\end{array}$

Daily motion: $\Delta \alpha=+I 6^{\mathrm{s}}, \Delta \delta=+\mathrm{I}^{\circ} 3^{\prime}$. Object diffuse, without central condensation or nucleus, nothing reported about tail.

$$
\left(08 \mathrm{rO}_{4}+\mathrm{I} 8282+00598+\mathrm{I} 5 \mathrm{IO} 3+200 \mathrm{I} 6+20103=82206\right) \text {. }
$$

\section{(2) Communication of an observed position}

The same scheme as under $(\mathrm{I})$ is used. The designation of the object may be shortened or omitted if no confusion is possible.

Example 2 (accurate position).

Telegram 1933 Feb. I8:

Peltier comète Delporte I7ogr février 2I50I 23003258458033667776 Stroobant.

Stroobant communicates the following observation of comet Peltier by Delporte:

1933

Feb. I7
U.T.

$$
2 \mathrm{I}^{\mathrm{h}} 5 \mathrm{O}^{\mathrm{m} \cdot \mathrm{I}}
$$

$\alpha_{1933 \cdot 0}$
$23^{\mathrm{h}} \mathrm{O}^{\mathrm{m}} 3 \mathrm{O}^{\mathrm{s}} \cdot 3$
Mag.

$+58^{\circ} 45^{\prime} 36^{\prime \prime}$ $9^{\mathrm{m}}$

Nothing reported about appearance of the object itself, nothing reported about tail.

$$
(\text { I } 709 \mathrm{I}+2 \mathrm{I} 5 \text { OI }+23003+25845+80336=\cdot 67776) \text {. }
$$

(3) Communication of other discoveries and observations

A scheme analogous to the scheme in (I) should be used as far as possible.

(4) Communication of parabolic and nearly parabolic orbits

(a) Name of discoverer or generally used name of object.

(b) Nature of object.

(c) Name of computer.

(d) The word parabola; or the words nearly parabolic followed by a group of five figures giving $e$, the eccentricity, in units of the fourth decimal (unit and four decimals).

(e) Month of perihelion time. In case the perihelion time is so far from the actual date that doubt may arise as to the year, a remark should follow under $(l)$

$(f)$ Group of five figures giving the day of the perihelion time (two figures) and decimals of a day (three figures) according to universal time. 
(g) Group of five figures giving $\omega$, the angle from node to perihelion, in degrees (three figures) and minutes of arc (two figures).

(h) Group of five figures giving $\Omega$, the longitude of the node, in degrees (three figures) and minutes of arc (two figures).

(i) Group of five figures giving $i$, the inclination, in degrees (three figures) and minutes of arc (two figures). For retrograde orbits $i>90^{\circ}$ by definition.

(j) Group of five figures giving $q$ (not $\log q$ ), the perihelion distance in units of the fourth decimal (unit and four decimals).

(k) Group of five figures (check number) computed as the sum of the preceding fivefigure groups. If this sum is a number of six figures, the left hand figure (first figure) is discarded.

(l) Remarks. It should be stated here if the equinox is not that of the beginning of the actual year (e.g. equinox I $90^{\circ} \circ$ or $195^{\circ} \circ$ ).

(m) Name of the communicator.

Example.

See Example 3 under (7) with parabolic elements and ephemeris.

(5) Communication of elliptic elements of comets and planets

(a) Name of discoverer or generally used name of object.

(b) Nature of object.

(c) Name of computer.

(d) The word ellipse.

(e) Month of the epoch.

(f) Group of five figures giving the day of the epoch (two figures) and decimals of a day (three figures) according to universal time.

(g) Group of five figures giving $M$, the mean anomaly at the epoch, in degrees (three figures) and minutes of arc (two figures).

(h) Group of five figures giving $\omega$, the angle from node to perihelion, in degrees (three figures) and minutes of arc (two figures).

(i) Group of five figures giving $\Omega$, the longitude of the node, in degrees (three figures) and minutes of arc (two figures).

(j) Group of five figures giving $i$, the inclination, in degrees (three figures) and minutes of arc (two figures). For retrograde orbits $i>90^{\circ}$ by definition.

$(k)$ Group of five figures giving $\phi$, the angle of eccentricity $(e=\sin \phi)$, in degrees (three figures) and minutes of arc (two figures).

(l) Group of five figures giving $\mu$, the mean daily motion, in units of one tenth of a second of arc.

( $m$ ) Group of five figures (check number) computed as the sum of the preceding fivefigure groups. If this sum is a number of six figures, the left hand figure (first figure) is discarded.

(n) Remarks. It should be stated here if the equinox is not that of the beginning of the actual year.

(o) Name of the communicator.

Example.

See Example 4 under (7) with elliptic elements and ephemeris.

(6) Communication of a circular orbit

The same scheme as under (5) is used with the following exceptions:

(d) The word circular is used instead of the word ellipse.

$(g),(h)$ One group of five figures giving $u$, the argument of the latitude $(u=\omega+v)$ at the epoch, in degrees (three figures) and minutes of arc (two figures) instead of the two groups giving $M$ and $\omega$.

(k) The group giving $\phi$ is omitted. 


\section{(7) Communication of an ephemeris}

(a) Name of discoverer or generally used name of object.

(b) Nature of object.

(c) Name of computer.

(d) The word ephemeris.

(e) Group of five figures giving the universal time of the dates of the ephemeris in hours (two figures), minutes (two figures) and tenths of a minute. If, as will nearly always be the case, this group would be ooooo corresponding to an ephemeris for ${ }^{\text {h }}$ U.T., then the group is omitted.

(f) The month of the first ephemeris date.

(g) Group of five figures, of which the first two give the day of the first ephemeris date, and the last three the light $\left(\frac{I}{r^{2} \Delta^{2}}\right)$ of the object on this date expressed in units of one tenth of the light at the date of discovery. If no information concerning light is to be communicated the three last figures should be $y y y$.*

$\left(h_{1}\right)$ Group of five figures giving the right ascension at the first ephemeris date in hours (two figures), minutes of time (two figures) and tenths of minutes of time.

$\left(i_{1}\right)$ Group of five figures giving the declination at the first ephemeris date. The first figure of the group is $\mathbf{I}$ or 2 according as the declination is negative or positive. The next two figures give the degrees, the last two figures the minutes of arc of the declination.

$\left(h_{2}\right),\left(i_{2}\right) \ldots$ Analogous groups for the other ephemeris dates.

(j) Group of five figures, of which the first two give the day of the last ephemeris date, and the last three the light $\left(\frac{I}{r^{2} \Delta^{2}}\right)$ of the object on this date expressed in units of one tenth of the light at the date of discovery. If no information concerning light is to be communicated the three last figures should be $y y y$.*

(k) Group of five figures (check number) computed as the sum of the preceding fivefigure groups. If this sum is a number of six figures, the first figure is discarded.

(l) Remarks. It should be stated here if the ephemeris places are not mean places for the beginning of the actual year.

(m) Name of the communicator.

\section{Example 3.}

Telegram from Kiel, I930 March 16 :

Beyer comet Ebell parabola April 22212 0264I II626 07r28 2059964206 ephemeris March I 7yyy 06052 2343606059 23613 06072 23745 0609I 239II 29yyy 64979 Ebell

Ebell has computed parabolic elements and an ephemeris of comet Beyer as follows:

$$
\begin{aligned}
& T=\text { I930 April 22:2I2 U.T. } \\
& \omega=26^{\circ} 4 \mathrm{I}^{\prime}
\end{aligned}
$$

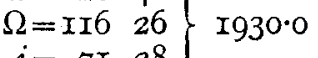

\begin{tabular}{|c|c|}
\hline$\alpha_{1930 \cdot 0}$ & $\delta_{1930 \cdot 0}$ \\
\hline $6^{\mathrm{h}} 5^{\mathrm{m} \cdot 2}$ & $+34^{\circ} 3$ \\
\hline $\begin{array}{lll}6 & 5 & 9\end{array}$ & 36 I \\
\hline $67 \cdot 2$ & 374 \\
\hline 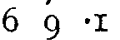 & $+39 I$ \\
\hline
\end{tabular}

$$
\begin{aligned}
& i=7 \text { I } 28\} \\
& q=2.0599 \\
& (222 I 2+0264 I+I I 626+07 I 28+20599=64206) . \\
& 0^{\text {h }} \text { U.T. }
\end{aligned}
$$

* See Remarks, p. 5 ro. 
No information concerning light is given.

$(\mathrm{I} 7000+06052+23436+06059+236 \mathrm{I} 3+06072+23745+0609 \mathrm{I}+$

Example 4.

$+239 I I+29000=\cdot 64979)$.

Telegram from Copenhagen, r933 Oct. 23:

Whipple comet Whipple Cunningham ellipse July 08430 ooooo I8210 I8809 01004 02407 043I3 53I73 ephemeris October 270I0 03I99 208370317520808 03I50 2074I 03124 20714 080I0 30768 Strömgren.

Strömgren communicates the following elliptic elements and ephemeris of comet Whipple computed by Whipple and Cunningham:

$$
\begin{aligned}
& T=\text { I933 July } 8 \cdot 430 \text { U.T. } \\
& \omega=\mathrm{I} 82^{\circ} 10^{\prime} \\
& \Omega=I 88 \quad 9\} \quad \text { I933.0 } \\
& i=\text { I0 } 4 \\
& \phi=24 \quad 7 \\
& \mu=43 I^{\prime \prime} \cdot 3 \\
& (08430+00000+\mathrm{I} 82 \mathrm{IO}+\mathrm{I} 8809+01004+02407+043 \mathrm{I} 3=53 \mathrm{I} 73) .
\end{aligned}
$$

The fact that the perihelion time is I 933 July 8.430 is expressed in the telegram by the statement (cf. the word July and the two first five-figure groups) that $M=0^{\circ} \mathrm{o}^{\prime}$ for the epoch I933 July $8 \cdot 430$.

$$
\begin{aligned}
& \mathrm{o}^{\text {h }} \text { U.T. } \\
& \text { I933 } \\
& \text { Nov. } 4
\end{aligned}
$$

\begin{tabular}{lll}
\multicolumn{3}{c}{$\alpha_{1933 \cdot 0}$} \\
$3^{\mathrm{h}}$ & $\mathrm{Ig}^{\mathrm{m} \cdot 9}$ \\
3 & $\mathrm{I} 7$ & $\cdot 5$ \\
3 & I5 & $\cdot 0$ \\
3 & I2 & $\cdot 4$
\end{tabular}

\section{Remarks:}

If it is desired to express in a telegram the fact that certain data are not given, a $y$ or $y$ 's are used instead of one or more figures in the five-figure groups, the $y$ 's to be counted equal to zero when the check number is computed.

\section{Examples:}

If it had been desired in Example I to give the time of observation as $18^{\mathrm{h}} 28^{\mathrm{m}}$, instead of $18^{\mathrm{h}} 28^{\mathrm{m}} \cdot 2$, the second five-figure group should have been $I 828 y$, instead of 18282 .

If it had been desired, in the same telegram, not to communicate any magnitude, the first five-figure group should have been 08yy4, instead of 08I04.

Attention should be drawn in connection with orbits and ephemerides to the following resolution adopted at the I.A.U. meeting in Leiden I928: "That the dates used for ephemerides of comets and minor planets shall be the midnight following an integral Julian date which is exactly divisible by 8 (or 4 , etc.)', and to the amendment adopted at the Zürich meeting I948: "That, from the beginning of the year I950, the dates employed in ephemerides of comets should be in intervals of ro days or 5 days, the dates being chosen to fit the standard 40-day dates'; further to the resolution accepted at the meeting in Paris I935: 'That for the year I935 the epoch of osculation July I7.o should be chosen and thereafter every 40oth day.'

November $\mathbf{I} 948$

Julie M. Vinter Hansen 


\section{CODE CHIFFRÉ POUR TÉLÉGRAMMES ASTRONOMIQUES}

accepté par l'Union Astronomique Internationale dans son Assemblée générale de Paris, juillet I935, modifié à l'Assemblée générale de Zürich, août I948, à utiliser à partir du Ier novembre 1948

\section{(I) Communication des découvertes de comètes ou de planètes}

La nature de l'objet, l'auteur de la découverte, l'instant de l'observation, la position, le mouvement, la magnitude et la description de l'aspect physique seront communiqués d'après le dispositif suivant:

(a) Nom de l'auteur de la découverte, ou, dans la communication de la redécouverte d'une comète périodique, la comète sera désignée par son nom habituel par exemple Neujmin I. L'auteur de la redécouverte d'une comète périodique sera traité comme l'observateur.

(b) Un mot décrivant la nature de l'objet: comète, planète ou objet.

(c) Nom de l'observateur.

(d) Groupe de cinq chiffres, donnant le jour du mois (deux chiffres), la magnitude (deux chiffres) et une communication relative à l'aspect physique de l'objet (un chiffre), d'après le schéma suivant:

\begin{tabular}{|l|c|c|c|}
\hline & $\begin{array}{c}\text { On ne signale } \\
\text { rien au sujet } \\
\text { d'une queue }\end{array}$ & Queue $<1^{\circ}$ & Queue $>1^{\circ}$ \\
\hline $\begin{array}{c}\text { Aspect stellaire } \\
\text { On ne signale rien sur l'aspect } \\
\text { de l'objet lui-même }\end{array}$ & 0 & 2 & 3 \\
$\begin{array}{c}\text { Objet diffus, sans condensation } \\
\text { centrale ou noyau } \\
\text { Objet diffus, avec condensation } \\
\text { centrale ou noyau }\end{array}$ & 4 & 5 & 6 \\
\hline
\end{tabular}

(e) Nom du mois.

(f) Groupe de cinq chiffres donnant l'heure de l'observation (en temps universel, compté à partir du minuit moyen de Greenwich). On indique les heures (deux chiffres), les minutes (deux chiffres) et les dixièmes de minute (un chiffre).

(g) Groupe de cinq chiffres donnant l'ascension droite observée (lieu moyen rapporté à l'équinoxe moyen du commencement de l'année, sauf indication contraire). On indique les heures (deux chiffres), les minutes de temps (deux chiffres), et, pour les positions approchées, les dixièmes de minute de temps (cf. Exemple I), tandis que pour les positions précises on donne la dizaine des secondes de temps (cf. Exemple 2).

(h) Groupe de cinq chiffres donnant la déclinaison observée (lieu moyen rapporté à l'équinoxe moyen du commencement de l'année, sauf indication contraire). Le premier chiffre du groupe est $\mathrm{x}$ ou 2, selon que la déclinaison est négative ou positive. Les deux chiffres suivants donnent les degrés, les deux derniers chiffres les minutes d'arc de la déclinaison.

(i) Groupe de cinq chiffres, dont le premier est toujours 8. Les deux chiffres suivants donnent les unités des secondes de temps et les dixièmes de seconde de temps de l'ascension droite (suite de $(g)$ ). Les deux derniers chiffres donnent les secondes d'arc de la déclinaison. On omet ce groupe lorsque la position observée n'est qu'approchée. 
(j) Groupe de cinq chiffres donnant le mouvement diurne de l'objet en ascension droite. Le premier chiffre du groupe est $x$ ou 2 selon que le mouvement diurne en ascension droite est négatif ou positif. Les deux chiffres suivants donnent les minutes de temps, les deux derniers chiffres les secondes de temps du mouvement diurne en ascension droite. On omet ce groupe lorsqu'on ne communique rien sur le mouvement de l'objet.

(k) Groupe de cinq chiffres donnant le mouvement diurne en déclinaison. Le premier chiffre du groupe est I ou 2 selon que le mouvement diurne en déclinaison est négatif ou positif. Les deux chiffres suivants donnent les degrés, les deux derniers chiffres les minutes d'arc du mouvement diurne en déclinaison. On omet ce groupe lorsqu'on ne communique rien sur le mouvement de l'objet.

(l) Groupe de cinq chiffres (nombre de contrôle), qui donne la somme des nombres précédents de cinq chiffres. Si cette somme est un nombre de six chiffres, on omet les centaines de mille (premier chiffre à gauche).

(m) Signature de l'expéditeur.

Exemple I (position approchée).

Télégramme du 9 janvier I935:

Johnson comet Johnson o8I04 January I8282 00598 I5I03 200 I6 20 I03 82206 Johannesburg Observatory.

Une comète nouvelle a été découverte par Johnson comme suit:

$\begin{array}{ccccc}\text { I935 } & \text { T.U. } & \alpha_{1935 \cdot 0} & \delta_{1935 \cdot 0} & \text { Mag. } \\ \text { janvier } 8 & \text { I } 8^{\mathrm{h}} 28^{\mathrm{m}} \cdot 2 & 0^{\mathrm{h}} 59^{\mathrm{m} \cdot 8} & -5 \mathrm{I}^{\circ} 3^{\prime} & \text { IO }^{\mathrm{m}}\end{array}$

Mouvement diurne: $\Delta \alpha=+16^{\mathrm{s}}, \Delta \delta=+I^{\circ} 3^{\prime}$. Objet diffus, sans condensation centrale ou noyau, on ne signale rien au sujet d'une queue.

$$
(08 \mathrm{IO} 4+\mathrm{I} 8282+00598+\mathrm{I} 5 \mathrm{IO} 3+200 \mathrm{I} 6+20103=82206) \text {. }
$$

\section{(2) Communication d'une position observée}

On emploie le même dispositif que pour (I). La désignation de l'objet peut être abréviée ou omise si aucune confusion n'est possible.

\section{Exemple 2 (position précise).}

Télégramme du I 8 février I933:

Peltier comète Delporte I709I février 2I5Or 23003258458033667776 Stroobant.

Stroobant communique l'observation suivante de la comète Peltier par Delporte:

$\begin{array}{ccccc}\text { I933 } & \text { T.U. } & \alpha_{1933 \cdot 0} & \delta_{1933 \cdot 0} & \text { Mag. } \\ \text { février I7 } & 2 I^{\mathrm{h}} 5 \mathrm{O}^{\mathrm{m} \cdot \mathrm{I}} & 23^{\mathrm{h}} \mathrm{O}^{\mathrm{m}} 30^{\mathrm{s}} \cdot 3 & +58^{\circ} 45^{\prime} 36^{\prime \prime} & 9^{\mathrm{m}}\end{array}$

On ne signale rien sur l'aspect de l'objet lui-même, on ne signale rien au sujet d'une queue.

$$
(\text { I } 709 \mathrm{I}+2 \mathrm{I} 5 \mathrm{OI}+23003+25845+80336=\cdot 67776) \text {. }
$$

\section{(3) Communication d'autres découvertes et observations}

On emploiera dans la mesure du possible un dispositif analogue au dispositif de (I).

\section{(4) Communication d'orbites paraboliques ou presque paraboliques}

(a) Nom de l'auteur de la découverte ou nom habituellement employé pour l'objet.

(b) Nature de l'objet.

(c) Nom du calculateur. 
(d) Le mot parabole; ou les mots presque parabolique suivis d'un groupe de cinq chiffres donnant l'excentricité $e$ en unités de la quatrième décimale (l'unité et quatre décimales).

(e) Le mois du passage au périhélie. Dans le cas où le périhélie serait tellement éloigné de la date de la dépêche que le doute fût possible quant à l'année, une note serait ajoutée en $(l)$.

(f) Groupe de cinq chiffres donnant le jour du périhélie (deux chiffres) et trois décimales du jour (trois chiffres), en temps universel.

(g) Groupe de cinq chiffres donnant $\omega$, angle nœud-périhélie, en degrés (trois chiffres) et minutes d'arc (deux chiffres).

(h) Groupe de cinq chiffres donnant $\Omega$, longitude du nœud, en degrés (trois chiffres) et minutes d'arc (deux chiffres).

(i) Groupe de cinq chiffres donnant $i$, inclinaison de l'orbite, en degrés (trois chiffres) et minutes d'arc (deux chiffres). Pour les orbites rétrogrades, $i>90^{\circ}$ par définition.

(j) Groupe de cinq chiffres donnant $q$, distance périhélie (et non $\log q$ ) en unités de la quatrième décimale (l'unité et quatre décimales).

(k) Groupe de cinq chiffres (nombre de contrôle), qui donne la somme des nombres précédents de cinq chiffres. Si cette somme est un nombre de six chiffres, on omet les centaines de mille (premier chiffre à gauche).

(l) Remarques. On dira ici si l'équinoxe utilisé n'est pas celui de l'année en cours ( $p$. ex. équinoxe $1900^{\circ} \circ$ ou $\left.\mathrm{I} 95^{\circ} 0^{\circ}\right)$.

(m) Signature de l'expéditeur.

Exemple.

Voir l'exemple 3 de (7) avec éléments paraboliques et éphéméride.

\section{(5) Communication d'éléments elliptiques de comètes et planètes}

(a) Nom de l'auteur de la découverte ou nom habituellement employé pour l'objet.

(b) Nature de l'objet.

(c) Nom du calculateur.

(d) Le mot ellipse.

(e) Mois de l'époque.

( $f$ ) Groupe de cinq chiffres donnant le jour de l'époque (deux chiffres) et décimales du jour (trois chiffres) en temps universel.

(g) Groupe de cinq chiffres donnant $M$, anomalie moyenne pour l'époque, en degrés (trois chiffres) et minutes d'arc (deux chiffres).

(h) Groupe de cinq chiffres donnant $\omega$, angle noud-périhélie, en degrés (trois chiffres) et minutes d'arc (deux chiffres).

(i) Groupe de cinq chiffres donnant $\Omega$, longitude du nœud, en degrés (trois chiffres) et minutes d'arc (deux chiffres).

(j) Groupe de cinq chiffres donnant $i$, inclinaison de l'orbite, en degrés (trois chiffres) et minutes d'arc (deux chiffres). Pour les orbites rétrogrades, $i>90^{\circ}$ par définition.

(k) Groupe de cinq chiffres donnant $\phi$, angle d'excentricité $(e=\sin \phi)$, en degrés (trois chiffres) et minutes d'arc (deux chiffres).

(l) Groupe de cinq chiffres donnant $\mu$, moyen mouvement, en unités du dixième de seconde d'arc.

(m) Groupe de cinq chiffres (nombre de contrôle), égal à la somme des groupes précédents de cinq chiffres en omettant, s'il y a lieu, les centaines de mille.

(n) Remarques. On dira ici si l'équinoxe utilisé n'est pas celui de l'année en cours.

(o) Signature de l'expéditeur.

\section{Exemple.}

Voir l'exemple 4 de (7) avec éléments elliptiques et éphéméride. 


\section{(6) Communication d'une orbite circulaire}

On emploiera le même dispositif que pour (5), avec les modifications suivantes:

(d) On remplace le mot ellipse par le mot circulaire.

$(g)$, (h) Groupe de cinq chiffres donnant $u$, argument de latitude $(u=\omega+v)$ à l'époque, en degrés (trois chiffres) et minutes d'arc (deux chiffres), au lieu de deux groupes donnant $M$ et $\omega$.

(k) On omet le groupe $\phi$.

\section{(7) Communication d'une éphéméride}

(a) Nom de l'auteur de la découverte ou nom habituellement employé pour l'objet.

(b) Nature de l'objet.

(c) Nom du calculatęur.

(d) Le mot éphéméride.

(e) Groupe de cinq chiffres donnant le temps universel des lieux de l'éphéméride en heures (deux chiffres), minutes (deux chiffres) et dixièmes de minute. Si, comme ce sera presque toujours le cas, ce groupe est ooooo, correspondant à une éphéméride pour $\mathrm{O}^{\mathrm{h}}$ T.U., on l'omet tout simplement.

$(f)$ Le mois se rapportant au premier lieu de l'éphéméride.

(g) Groupe de cinq chiffres, dont les deux premiers donnent le jour du mois du premier lieu de l'éphéméride, et les trois derniers l'éclat $\left(\frac{I}{r^{2} \Delta^{2}}\right)$ de l'objet à cette date, exprimé en unités de la première décimale de l'éclat à la date de la découverte. Si on ne communique pas de données sur l'éclat, les trois derniers chiffres du groupe seront yyy.*

$\left(h_{1}\right)$ Groupe de cinq chiffres donnant l'ascension droite du premier lieu de l'éphéméride, en heures (deux chiffres), minutes de temps (deux chiffres) et dixièmes de minute de temps.

(i $)$ Groupe de cinq chiffres donnant la déclinaison du premier lieu de l'éphéméride. Le premier chiffre du groupe est I ou 2 selon que la déclinaison est négative ou positive. Les deux chiffres suivants donnent les degrés, les deux derniers les minutes d'arc de la déclinaison.

$\left(h_{2}\right),\left(i_{2}\right) \ldots$ Groupes analogues pour les autres lieux de l'éphéméride.

(j) Groupe de cinq chiffres, dont les deux premiers donnent le jour du dernier lieu de l'éphéméride, et les trois derniers l'éclat $\left(\frac{I}{r^{2} \Delta^{2}}\right)$ de l'objet à cette date, exprimé en unités de la première décimale de l'éclat à la date de la découverte. Si l'on ne communique pas de données sur l'éclat, les trois derniers chiffres du groupe seront yyy.*

(k) Groupe de cinq chiffres (nombre de contrôle) égal à la somme des groupes précédents, en omettant, s'il y a lieu, les centaines de mille.

(l) Remarques. On dira ici si les lieux de l'éphéméride sont rapportés à un autre équinoxe que celui du commencement de l'année en cours.

(m) Signature de l'expéditeur.

\section{Exemple 3.}

Télégramme de Kiel, I6 mars r930:

Beyer comète Ebell parabole Avril 222I2 0264I II626 07I28 2059964206 éphéméride mars I7yyy 060522343606059236130607223745 o609I 239 II $29 y y y 64979$ Ebell.

\footnotetext{
* Voir Remarques, p. 5I5.
} 
Ebell a calculé des éléments paraboliques et une éphéméride de la comète Beyer, comme suit:

$$
\begin{aligned}
& T=\text { I930 avril } 22 \cdot 2 \mathrm{I} 2 \mathrm{~T} . \mathrm{U} \text {. } \\
& \omega=26^{\circ} 4 I^{\prime} \\
& \Omega=\text { II6 } 26\} \text { I930.0 } \\
& i=7 \text { I } 28 \\
& q=2 \cdot 0599 \\
& (222 I 2+0264 I+I I 626+07 I 28+20599=64206) . \\
& \mathrm{o}^{\text {h }} \text { T.U. } \\
& \text { I930 } \\
& \text { Mars I7 } \\
& \alpha_{1930 \cdot 0} \\
& 6^{\mathrm{h}} 5^{\mathrm{m} \cdot 2} \\
& \begin{array}{lll}
6 & 5 & \cdot 9
\end{array} \\
& \begin{array}{lll}
6 & 7 & \cdot 2
\end{array} \\
& \begin{array}{lll}
6 & 9 & \cdot I
\end{array} \\
& \delta_{1930 \cdot 0} \\
& 2 \text { I } \\
& 25 \\
& 29
\end{aligned}
$$

On ne donne pas d'information au sujet de l'éclat.

$$
\begin{aligned}
& (\mathrm{I} 7000+06052+23436+06059+236 \mathrm{I} 3+06072+23745+0609 \mathrm{I}+ \\
& +239 \mathrm{II}+29000=64979) .
\end{aligned}
$$

\section{Exemple 4.}

Télégramme de Copenhague, I933 octobre 23:

Whipple comet Whipple Cunningham ellipse July 08430 ooooo I82 Io I8809 oro04 024070431353173 ephemeris October 27010 03I99 208370317520808 03I50 2074I 03I24 207I4 080ro 30768 Strömgren.

Strömgren communique les éléments elliptiques et l'éphéméride suivants de la comète Whipple, calculés par Whipple et Cunningham:

$$
\begin{aligned}
& T=\text { I933 juillet } 8 \cdot 430 \text { T.U. } \\
& \left.\omega=I 82^{\circ} I 0^{\prime}\right) \\
& \Omega=\mathbf{I} 88 \quad 9\} \mathbf{I} 933^{\circ} 0 \\
& i=\text { Io } 4 \\
& \phi=24 \quad 7 \\
& \mu=43 \mathrm{II}^{\prime \prime} \cdot 3 \\
& (08430+00000+\mathrm{r} 8210+\mathrm{I} 8809+01004+02407+043 \mathrm{I} 3=53 \mathrm{I} 73) .
\end{aligned}
$$

Le passage au périhélie au 1933 juillet 8.430 T.U. est exprimé dans le télégramme par le fait (cf. le mot juillet et les deux premiers groupes de cinq chiffres) que $M=0^{\circ} \mathrm{O}^{\prime}$ pour l'époque I933 juillet $8 \cdot 430$.

$\mathrm{o}^{\mathrm{h}}$ T.U.

$$
\begin{aligned}
& \text { I933 } \\
& \text { Oct. } 27 \\
& \alpha_{1933 \cdot 0} \\
& \delta_{1939 \cdot 0} \quad \text { Éclat } \\
& 3^{\mathrm{h}} 19^{\mathrm{m} \cdot 9} \\
& \begin{array}{llll}
3 & \mathrm{I} 7 & \cdot 5
\end{array} \\
& +8^{\circ} 37^{\prime} \\
& 88 \\
& 3 \text { I5 } 0 \quad 74 \mathrm{I} \\
& \text { Nov. } \begin{array}{r}
4 \\
8
\end{array} \\
& 3 \text { I2 } \cdot 4 \\
& +7 \mathrm{I} 4 \\
& \text { I.O } \\
& I \cdot O \\
& (27010+03199+20837+03175+20808+03150+2074 I+ \\
& +03124+20714+08010=\cdot 30768)
\end{aligned}
$$

\section{Remarques:}

Si l'on désire exprimer dans un télégramme le fait que l'on ne peut pas communiquer certaines données, on remplace par un $y$ ou plusieurs $y$ un ou plusieurs des chiffres du groupe à cinq chiffres, le $y$ étant compté comme équivalent à zéro lors du calcul du nombre de contrôle. 


\section{Exemples:}

Si l'on désirait, à l'exemple I (position approchée), donner l'heure de l'observation de $I 8^{\mathrm{h}} 28^{\mathrm{m}}$, au lieu de $18^{\mathrm{h}} 28^{\mathrm{m}} \cdot 2$, le deuxième groupe à cinq chiffres serait $\mathrm{I} 828 y$, au lieu de $I 8282$.

Si l'on désirait, dans le même télégramme, ne communiquer aucune magnitude, le premier groupe à cinq chiffres serait 08yy4, au lieu de 08 ro4.

En ce qui concerne les orbites et les éphémérides, il convient d'attirer l'attention sur la résolution suivante adoptée à l'assemblée de l'U.A.I. de Leyde, I928: 'Que les dates employées pour les éphémérides de comètes et de petites planètes seront comptées à partir de minuit suivant une date Julienne entière qui soit exactement divisible par 8 (ou par 4, etc.)', avec la modification apportée à l'assemblée de Zürich en I948: 'Que, à partir du début de l'année I950, les dates employées pour les éphémérides de comètes aient un intervalle de Io jours ou de 5 jours, les dates étant choisies de manière à correspondre aux dates standard échelonnées de 40 en 40 jours', et sur la résolution acceptée à l'assemblée de Paris, I935: 'Que pour l'année I935 on fasse choix de l'époque d'osculation juillet $\mathrm{I} 7^{\circ} \mathrm{O}$ et ensuite d'époques séparées de la première par des intervalles de 400 jours.'

Novembre $\mathbf{1 9 4 8}$

JUlie M. VinTER HANSEN 